\title{
Histological and Immunohistochemical Study on the Effect of Constant Light Exposure on T Lymphocyte Subsets in the Thymus and Lymph Node of Male Albino Rats
}

\author{
Original \\ Article \\ Rehab A. Rifaai and Fatma Al zhraa F. Abd El Baky ${ }^{2}$ \\ ${ }^{1}$ Department of Histology, Faculty of Medicine, Minia University, Minia, Egypt \\ ${ }^{2}$ Department of Anatomy, Faculty of Medicine, Minia University, Minia, Egypt
}

\begin{abstract}
Background: Today there is a widespread exposure to high levels of light at night. . This causes divergence from the natural environment and leads to significant implications on the circadian rhythm. Constant light exposure inhibits melatonin secretion and increases serum concentration of corticosterone. The immune system is very sensitive to stress.

Aim of the Work: to study the effect of chronic exposure to constant light (as a model of stress) on the T lymphocytes populations and distribution in the thymus and lymph node.

Material and Methods: animals were divided into two groups (10 rats each). The 1st group considered as control group, was kept on a day light-darkness for 12-12 h. The 2nd group was kept under complete artificial light for a period of 4 weeks. Thymus glands and the cervical lymph nodes of rats were removed and processed for haematoxylin and eosin, and immunohistochemical staining for CD3, CD4 and CD8.

Results: lymphocytic depletion was noticed in the thymus and lymph nodes of the constant light exposed group. Also the distribution of CD3 and CD4 positive cells were altered in the lymph node of the same group.

Conclusion: Constant light stress causes lymphocytic depletion and alters lymphoid cell subsets distribution both in the thymus and lymph nodes.
\end{abstract}

Key Words: Immune, light system, stress.

Received: 30 April 2016, Accepted: 30 April 2017

Corresponding Author: Rehab Ahmed Rifaai, Tel.: 01003358376, E-mail: rehabrifaai@yahoo.com

ISSN: 1110-0559, March 2017, Vol. 40, No. 1

\section{INTRODUCTION}

The circadian system consists of a central 'biological master clock', located in the suprachiasmatic nucleus (SCN) of the hypothalamus. It is thought to be the pacemaker of the circadian system ${ }^{[1]}$. It is affected by light and darkness through the retino-hypothalamic tract, which connects the retinal ganglion cells to the $\mathrm{SCN}$ in the hypothalamus, which also connected with the pineal gland through the superior cervical ganglion ${ }^{[2]}$.It was reported that exposure to light reduces the ability of the pineal gland of rats to synthesize melatonin ${ }^{[3]}$. Light stimuli are transduced into neuroendocrine signals by the cyclic circadian synthesis and release of melatonin by the pineal gland ${ }^{[4]}$. Melatonin is the main pineal neuro-hormone ${ }^{[5]}$. Periods of constant darkness and constant light cause stimulation and inhibition of melatonin secretion ${ }^{[6]}$. Adventure of electrical light disrupts the natural light-dark cycle for many humans and animals. Light exposure is no longer limited to the natural pattern $^{[7]}$. This affects many physiological and behavioral functions ${ }^{[8]}$. Sustained night-time illumination increases the risk of heart diseases ${ }^{[9]}$, cancer $^{[10]}$ and causes sleep and mood disturbances ${ }^{[11]}$. Nocturnal lighting, if sufficiently bright, disrupts the synthesis of melatonin ${ }^{[12]}$. There is a functional connection between pineal gland, and melatonin from one side with the immune system ${ }^{[13]}$. It is known that modulation of both the circadian system and melatonin affects immunological measures ${ }^{[7]}$.

Melatonin had a strong stimulating effect on the lymphocytes. It affects T lymphocytes and macrophages ${ }^{[14]}$.

Constant light housing has been shown to increase corticosterone levels and is used as an experimental 
model of chronic stress ${ }^{[15]}$. Acute or chronic stress induces immunomodulatory effects in animal models as well as in humans ${ }^{[16]}$.

The function of the immune system is highly regulated and mediates a specific cellular defense against foreign particles and pathogens ${ }^{[17]}$.

Thymus gland is the first of the lymphoid organs to be formed and grows considerably immediately after birth. Bone marrow derived progenitor cells undergo differentiation/maturation, within the thymus, to form the functional $\mathrm{T}$ cells ${ }^{[18]}$. CD3 is initially expressed in the cytoplasm of pro-thymocytes, which is the stem cells from which T-cells arise. pro-thymocytes differentiate into thymocytes, and then into medullary thymocytes, at this stage, CD3 antigen migrates to the cell membrane and is found bound to the membranes of mature T-cells ${ }^{[19]}$.

In the lymph nodes, $\mathrm{T}$ lymphocytes encounter and are recognized, through their variable $\mathrm{T}$ cell receptors (TCR), peptidic fragment of the antigen $(\mathrm{Ag})$ in association with the major histocompatibility complex (MHC) on antigen presenting cells (APCs). This recognition provides downstream signaling that induces $\mathrm{T}$ cell proliferation and differentiation into effector cells ${ }^{[20]}$.

$\mathrm{T}$ cells are involved in cell mediated immunity and are divided by the expression of $\mathrm{CD} 4+$ or $\mathrm{CD} 8+$ markers. $\mathrm{CD} 4+\mathrm{T}$ helper cells recognize antigens which are bound to MHC II complexes and are involved with the control of intracellular and extracellular pathogens. Cytotoxic CD8+ $\mathrm{T}$ cells recognize the MHC I complex and destroy infected or neoplastic cells ${ }^{[21]}$.

It was reported that different hormones can alter the balance of $T$ cell subsets ${ }^{[22]}$.

\section{AIM OF THE WORK}

The aim of the present work was to study the effect of chronic exposure to constant light (as a model of stress) on the $\mathrm{T}$ lymphocytes populations and distribution in the thymus and lymph node.

\section{MATERIALS AND METHODS}

\section{I-Animals:}

This study was conducted in Anatomy and Histology Departments, Faculty of Medicine, El-Minia University. Twenty male albino rats aged 4 weeks $(50-60 \mathrm{~g})$ obtained from the Faculty of agriculture, Minia University were used. Rats were housed in a clean plastic cage, and were given regular diet and water ad-libitum under controlled conditions. The experiment was approved by the ethical committee for animal handling for research work in ElMinia University.

\section{II- Experimental Design:}

The animals were divided into two groups (10 rats each). The 1st group considered as control group, was kept on a daylight-darkness for 12- $12 \mathrm{~h}$. The 2 nd group was kept under complete artificial light for a period of 4 weeks $^{[23]}$.

At the end of the experiment, following ether anesthesia, all animals were sacrificed. The thymus glands and the submandibular cervical lymph nodes of rats were removed. After dissection, the organs were fixed in $10 \%$ buffered formalin solution and for further histological examinations the specimens were embedded in paraffin, $5 \mu \mathrm{m}$ sections were cut and stained with hematoxylin and eosin ${ }^{[24]}$. Other $5 \mu \mathrm{m}$ sections were used for immunohistochemical (IHC) studies.

\section{Staining procedures for immunohistochemistry (IHC):}

Polyclonal rabbit antihuman anti-CD3 antibody (1:50 dilution, provided in liquid form. In $0.05 \mathrm{~mol} / \mathrm{L}$ Tris $/ \mathrm{HCl}$, $0.1 \mathrm{~mol} / \mathrm{L} \mathrm{NaCl}, 15 \mathrm{mmol} / \mathrm{L} \mathrm{NaN3}$. Dako. Denmark) was used for the identification of $\mathrm{T}_{\text {cells }}{ }^{[25]}$. Monoclonal mouse antihuman CD4 antibody (1:50 dilution, provided in liquid form in a buffer containing stabilizing protein and 0.015 mol/L sodium azide. Clone: 4B12. Dako. Denmark) was used for identification of $\mathrm{T}$ helper cells ${ }^{[26]}$. Monoclonal mouse antihuman CD8 antibody (ready-to-use, provided in liquid form in a buffer containing stabilizing protein and $0.015 \mathrm{~mol} / \mathrm{L}$ sodium azide. Clone: C8144/B. Dako. Denmark) was used for labeling cytotoxic T cells ${ }^{[27]}$.

Slides were deparaffinized, rehydrated, rinsed in tap water, and embedded in $3 \% \mathrm{H}_{2} \mathrm{O}_{2}$ for 10 min to block endogenous peroxidase. Then sections were treated with $2 \%$ trypsin for $10 \mathrm{~min}$. Non specific protein binding was blocked by a blocking solution (PBS and 10\% normal goat serum). Sections were incubated with primary antiCD3 antibody, anti-CD4 antibody and anti-CD8 antibody for $30 \mathrm{~min}$. Then sections were washed 3 times each for 5 minutes in buffer and incubated for further 30 minutes with the secondary antibodies diluted 1:1000, followed by washing. Following further 30 minutes incubation with Vectastain ABC kits (Avidin, Biotinylated horse radish peroxidase Complex) and washing for 10 minutes, the substrate, diaminobenzidine tetra hydrochloride (DAB) in distilled water was added for 5- $10 \mathrm{~min}$. The slides were lightly counterstained by hematoxylin ${ }^{[28]}$. The same method was applied to prepare negative control sections but the primary antibody was not added. The positive control tissues were human $T$ cell lymphoma tissue (obtained from the pathology department) for CD3 and rat spleen for CD4 and CD8. 


\section{III- Image capture:}

Images of fields were digitally captured in bright-field mode using a hardware consisting of a high-resolution color digital camera mounted on an Olympus microscope (Olympus, Japan), connected to a computer, and then analyzed using Adobe Photoshop.

\section{IV-Morphometric study:}

The number of CD4 and CD8 immunopositive cells was counted. Measurements were taken in 10 randomly selected non-overlapping fields from the animals of each group $^{(29)}$. All Morphometric measurements were taken at total magnification X1000.

\section{V-Statistical analysis:}

Morphometric data obtained were expressed as mean $\pm \mathrm{SD}$. Differences among the groups were analyzed via student $t$ test to compare between two groups (SPSS, version 13 SPSS Inc., Chicago, IL, USA). $P$-value $<0.05$ was considered statistically significant.

\section{RESULTS}

\section{I- Histological study}

In group I the thymus was partially subdivided into lobules separated by thin bands of connective tissue septa. Each lobule was divided into peripheral dark stained cortex and central pale stained medulla. The medulla was less densely cellular than the cortex, with many epithelial reticular cells and Hassall's corpuscles. The cortex and medulla were separated by a highly vascular corticomedullary zone (Figs.1A, 1B \& 1C). In group II the thymic cortex had many pale stained areas. These pale areas showed lymphocytic depletion with the exposure of epithelial reticular cells. Many lymphocytes were shrunk with pyknotic nuclei. Many degenerated thymic epithelial reticular cells appeared in the medulla (Figs. 2A, 2B\& 2C).

\section{II- Immuohistochemical study}

CD3 antibody stains human T cells in human T cell lymphoma tissue (Fig. 3A), CD4 and CD8 antibodies stain $\mathrm{T}$ cells in periarterial sheath of white pulp of the spleen and in the splenic sinuses (Figs. 3B\&C).

\section{Expression of CD3:}

In group I thymus sections showed high cortical expression with moderate medullary expression (Fig. 4A). On the cellular level the expression of CD3 occurred in the cytoplasm in a peri-nuclear location of the small thymocytes, while in large $\mathrm{T}$ lymphocytes CD3 antigen was found on the cell surface (Fig. 4B).
Immunoperoxidase staining for CD3 in group II thymus samples revealed moderate immunoreactivity mainly in the medulla with low expression in the cortex (Fig. 5A). On the cellular level the expression of CD3 occurred in the cytoplasm in a peri-nuclear location of the small thymocytes. Cytoplasmic CD3 expression was lost and the CD3 antigen was found on the cell surface of large $\mathrm{T}$ lymphocytes. Less frequent positive stained small thymocytes were noticed than the previous group (Fig. 5B).

\section{Expression of CD4:}

In group I the expression was limited to few thymocytes (Fig.6). In group II thymuses showed scattered immune reactive cells in the cortex and at the border between cortex and medulla. The density cytoplasmic reactivity, others showed faint expression (Fig. 7).

\section{Expression of CD8:}

In group I, many immunopositive cells were scattered throughout the sections (Fig. 8). In group II thymuses, few scattered immune reactive cells were difficulty noticed at the corticomedullary junction (Fig. 9).

\section{Counting of CD4 and CD8 positive cells in the thymus:}

There was a significant decrease in the number of CD4 and CD8 positive cells $(P=0.01,0.02)$ in group II compared with the control (Table 1).

Sections of the lymph node of group 1 were formed of a darker cortex at the periphery of the node with either primary or secondary nodules. Secondary nodule had pale stained germinal centre with peripheral dark corona. In the middle of the lymph node was the medulla with its dark cords of dense lymphocyte population. The medullary cords were surrounded by the medullary sinuses (Fig. 10). The lymph node cortex of group II had areas of depleted lymphocyte and disorganized small lymphatic follicles. The medullary sinuses were wide and dilated (Fig. 11).

\section{Expression of CD3:}

In group I high expression in the subcapsular area and in the paracortex with minimal expression in the lymphatic follicles was noticed. (Fig. 12A). In group II, The expression was lower than the previous group. High expression was noticed within the lymphatic follicles 
while the paracortex zone showed low expression. Some positive stained T-cells noticed in the medulla (Fig. 12B).

\section{Expression of CD4:}

In group I the positive immunostained cells were observed in the paracortex and within the medulla while the lymphatic follicles showed negative expression (Fig. 13A). In group II high expression were noticed especially in the lymphoid follicles, paracortex zone and in the medulla (Fig. 13B).

\section{Expression of CD8:}

In group I numerous positive immunostained cells appeared in the medulla (Fig. 13A), while in group II negative expression was noticed in both cortex and medulla (Fig. 14B).

Table 1. Effect of constant light on the mean number of CD4 and CD8 positive cells in the thymus a significant difference comparing group II with the group I

\begin{tabular}{lccc}
\hline & Group I & Group II Mean \pm SD & P value \\
Mean \pm SD & $1.7 \pm .14$ & $0.9 \pm 0.6$ & $0.01^{\text {a }}$ \\
CD8 & $0.88 \pm 0.3$ & $0.36 \pm 0.32$ & $0.02^{\text {a }}$ \\
\hline
\end{tabular}

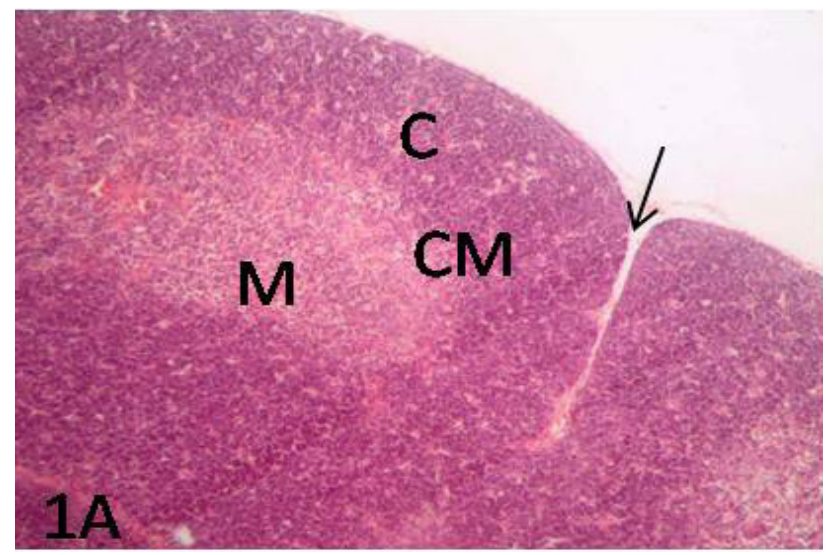

Fig. 1A: A Photomicrograph of the thymus of group I showing the thymus is partially subdivided into lobules separated by thin of connective tissue septae (arrow). Each lobule is divided int dark stained cortex $(\mathrm{C})$, pale stained medulla $(\mathrm{M})$ and corticomedullary junction $(\mathrm{CM})$.

$\mathrm{X} 100(\mathrm{H} \& \mathrm{E})$

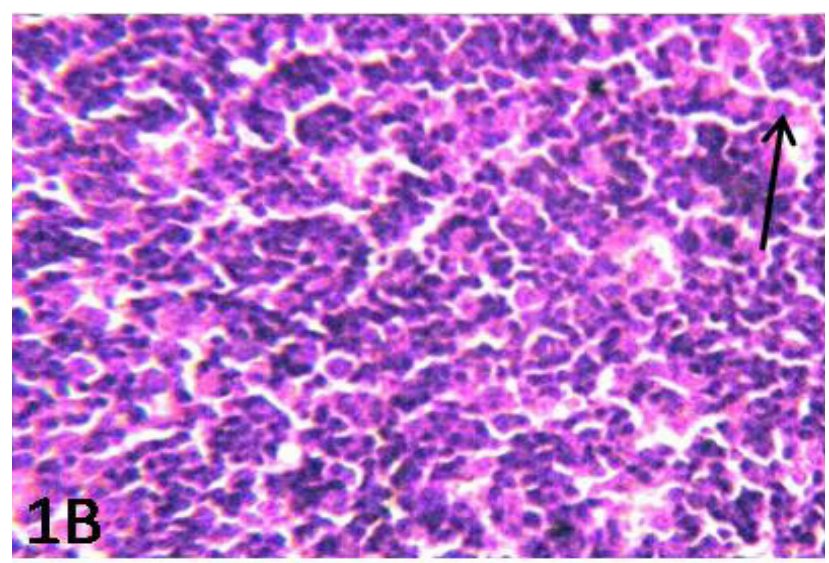

Fig. 1B: Higher magnification of the thymic cortex showing the sparse epithelial cells (arrow) are overshadowed by the abundant small lymphocytes.

(X400) ( H\& E)

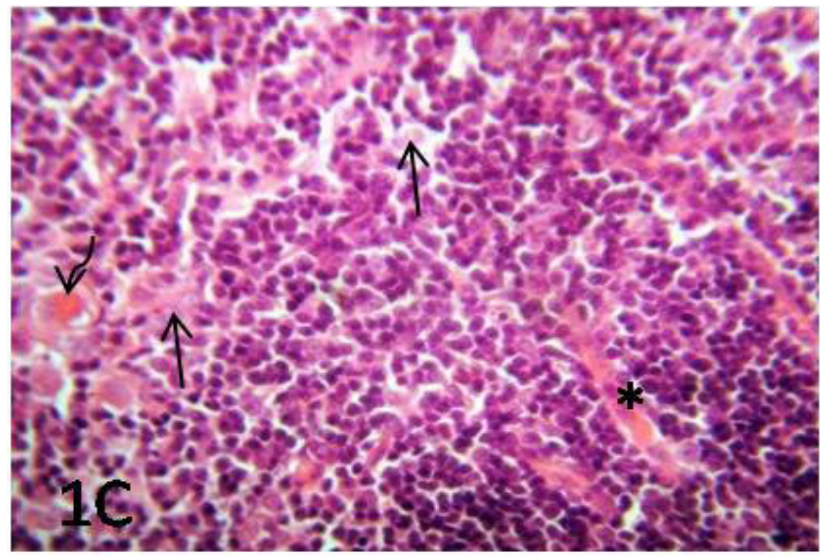

Fig. 1C: Higher magnification of the thymic medulla showing less cellular density than the cortex, and contains more prominent epithelial cells (arrow) and Hassalls corpuscles ( curved arrow). Notice plentiful blood vessels at the corticomedullary junction $(*)$.

X 400 ( H\& E)

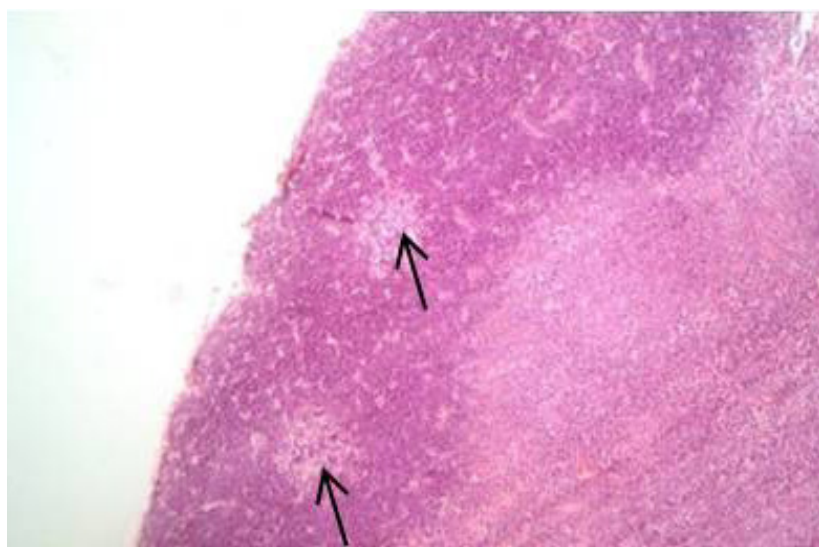

Fig. 2A: A Photomicrograph of the thymus of group II showing the cortex with many pale stained areas (arrows)

X100 ( H\& E) 


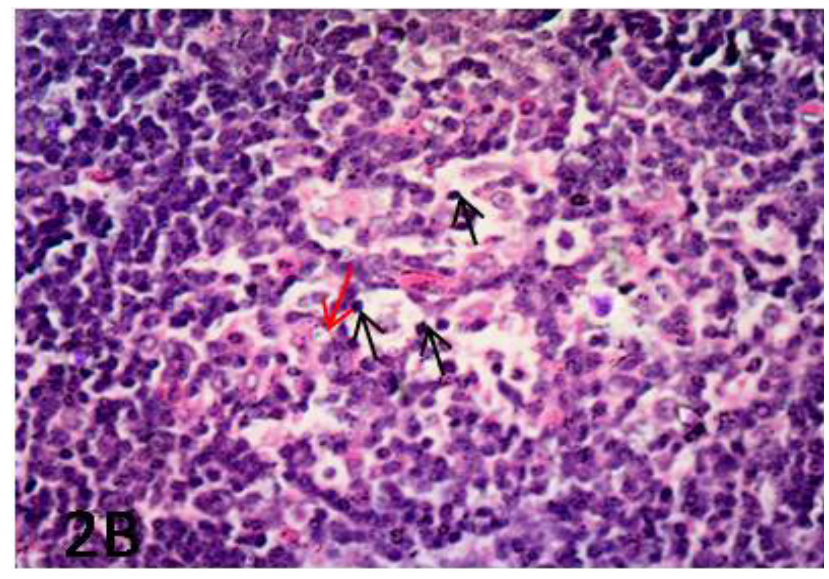

Fig. 2B: A higher magnification of one of the pale stained cortical area of the thymus of group II showing lymphocytic depletion with the exposure of epithelial cells (red arrow). Many lymphocytes are shrunk with pyknotic nuclei (black arrows). X400 ( H\& E)

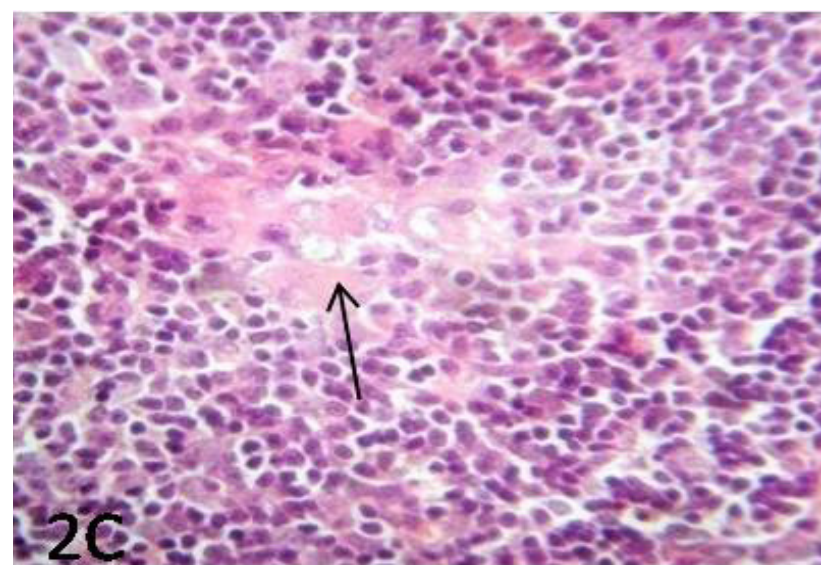

Fig. 2C: A higher magnification of the thymic medulla of group II showing large area of degenerated thymic epithelial cells (arrow).

X400 ( H\& E)

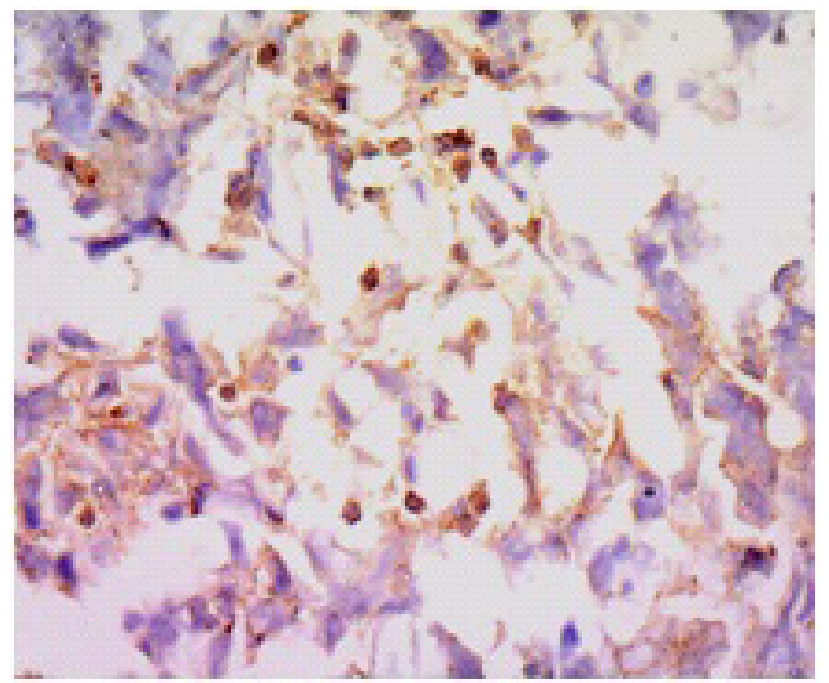

Fig. 3A: Positive control section of IHC for CD3 prepared from human $\mathrm{T}$ cell lymphoma tissue (arrow).

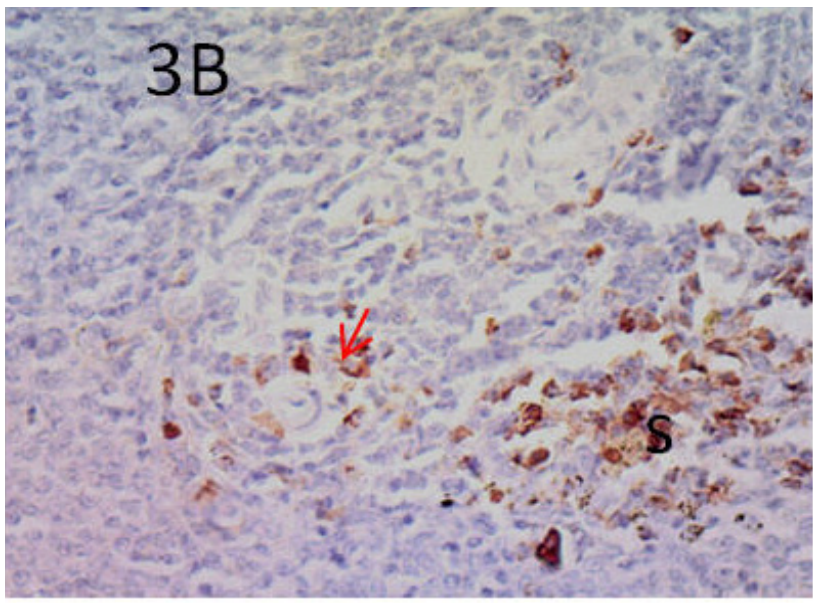

Fig. 3B: Positive control section of IHC for CD4 prepared from rat splenic tissue, showing positive stained $\mathrm{T}$ cells in periarterial sheath (red arrow) and in sinuses (s).

$\mathrm{X} 400$

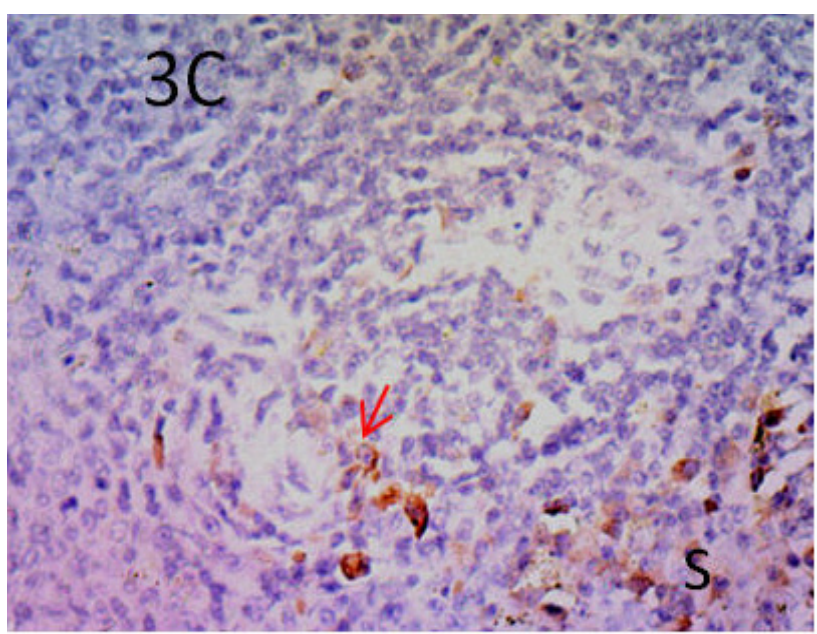

Fig. 3C: Positive control section of IHC for CD8 prepared from rat splenic tissue, showing positive stained $\mathrm{T}$ cells in periarterial sheath (red arrow) and in sinuses (s).

$\mathrm{X} 400$

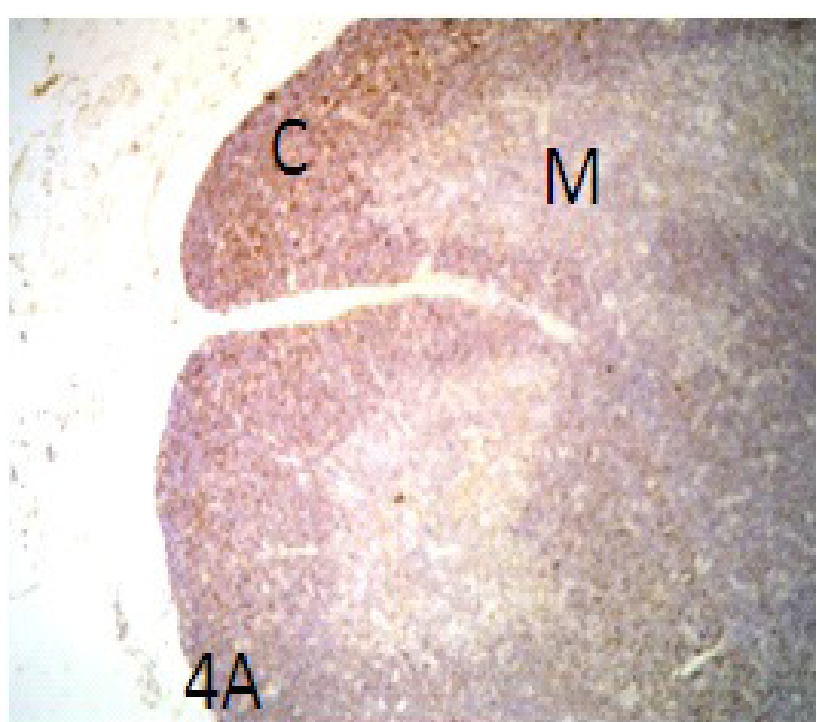

Fig. 4A: A photomicrograph of the thymus of group I immunostained for CD3 showing high expression in the cortex (C), and moderate expression in the medulla (M).

Immunoperoxidase reaction for $\mathrm{CD} 3 \mathrm{X} 100$ 


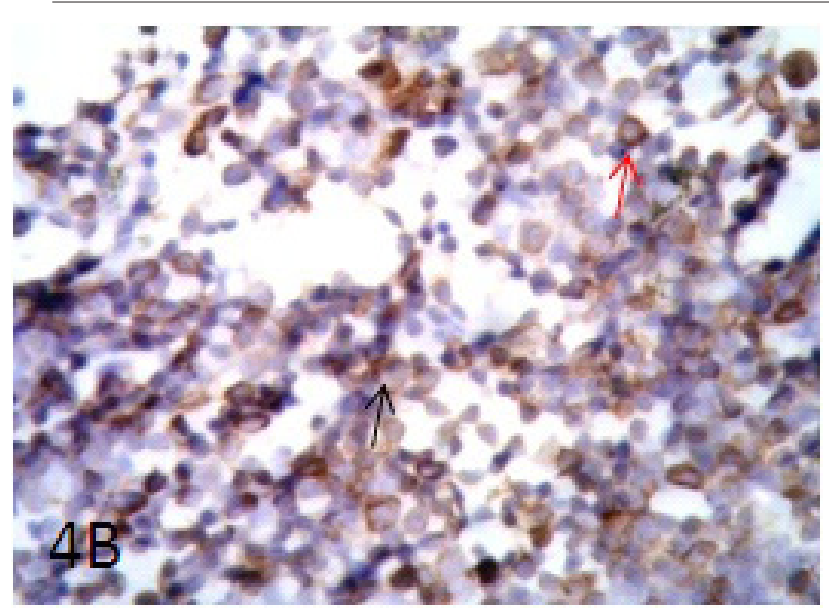

Fig. 4B: A higher magnification of the immunopositive cells of group I thymus tissue showing peri-nuclear cytoplasmic expression in small thymocytes (red arrow). Large $\mathrm{T}$ lymophcytes showing positive expression on the cell surface (black arrows). $\mathrm{X} 1000$ Immunoperoxidase reaction for CD3

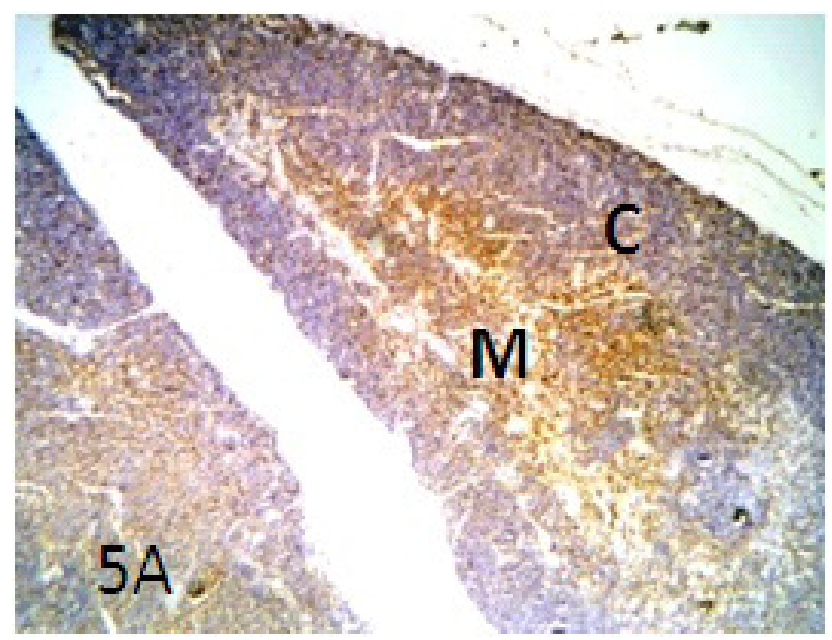

Fig. 5A: A photomicrograph of the thymus of group II immunostained for $\mathrm{CD} 3$ showing moderate expression in the medulla (M), and low expression in the cortex (C)

Immunoperoxidase reaction for CD3 X100

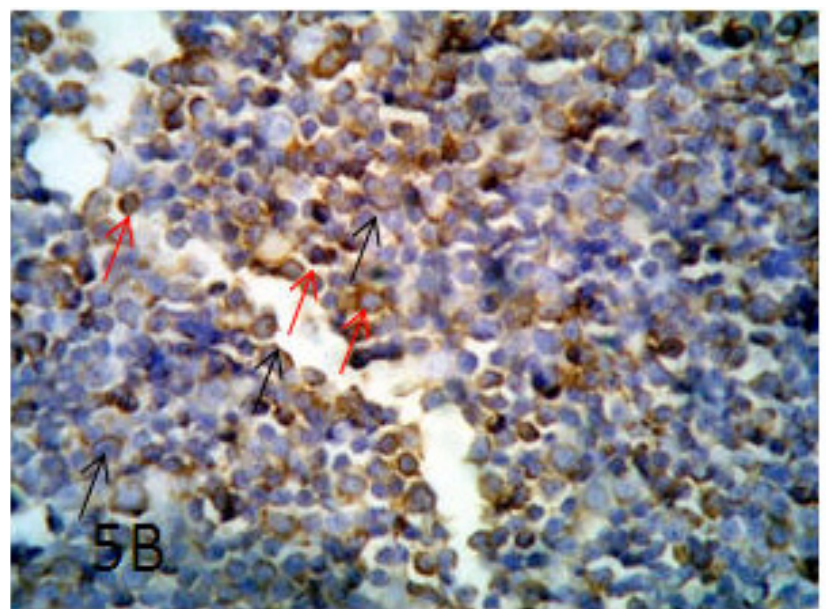

Fig. 5B: A higher magnification of the immunopositive cells showing peri-nuclear cytoplasmic expression in small thymocytes (red arrow). Many large $\mathrm{T}$ lymophcytes showing positive expression on the cell surface (black arrows).

X1000 Immunoperoxidase reaction for CD3

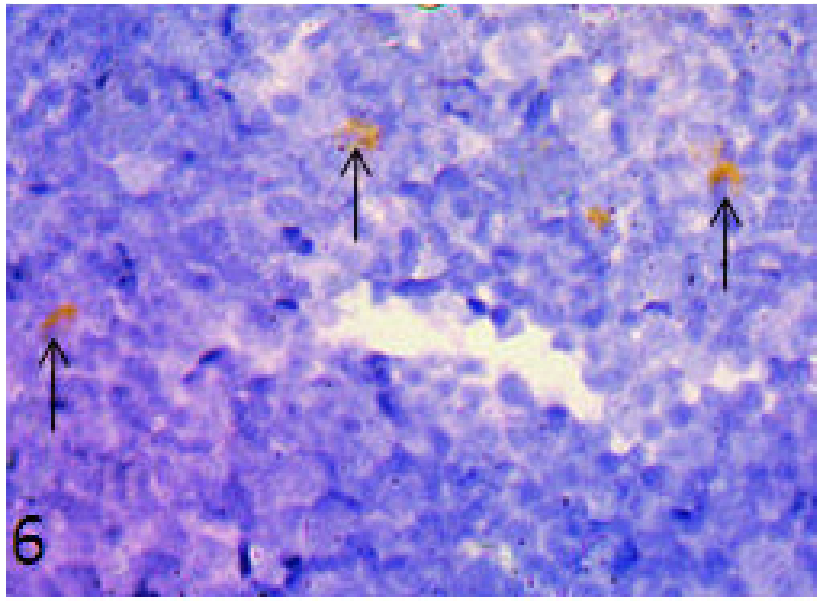

Fig. 6: A photomicrograph of the thymus of group I immunostained for $\mathrm{CD} 4$ showing immunopositive $\mathrm{T}$ lymphocytes (black arrows). Immunoperoxidase reaction for CD4X1000

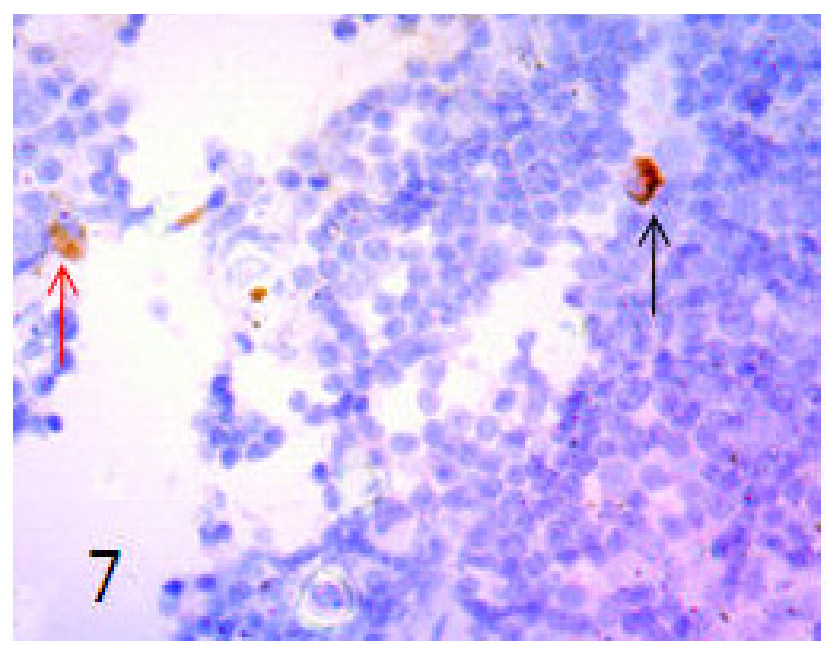

Fig. 7: A photomicrograph of the thymus of group II immunostained for CD4 showing dense cytoplasmic expression in the immunopositive cell (black arrow), others with faint reactivity (red arrow). Immunoperoxidase reaction for CD4X1000

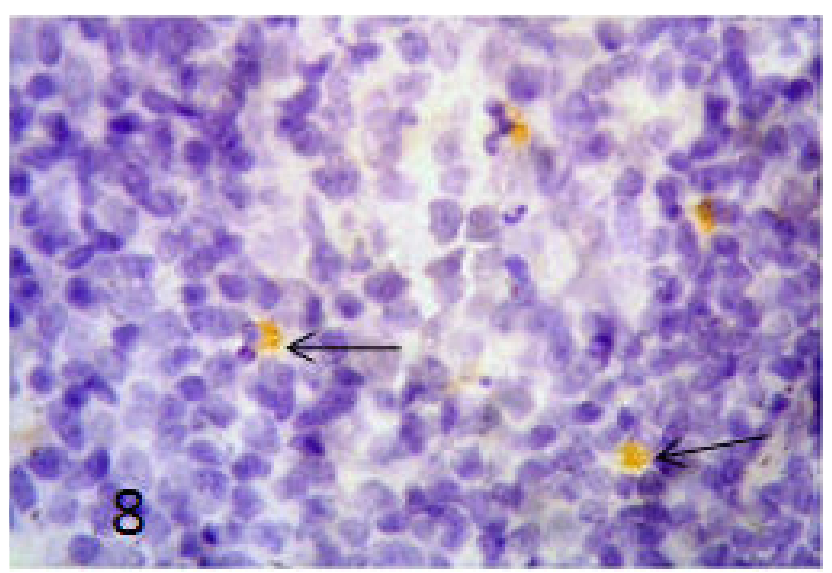

Fig. 8: A photomicrograph of the thymus of group I immunostained for CD8 showing many immunopositive cells with cytoplasmic expression (black arrows).

Immunoperoxidase reaction for CD8X1000 


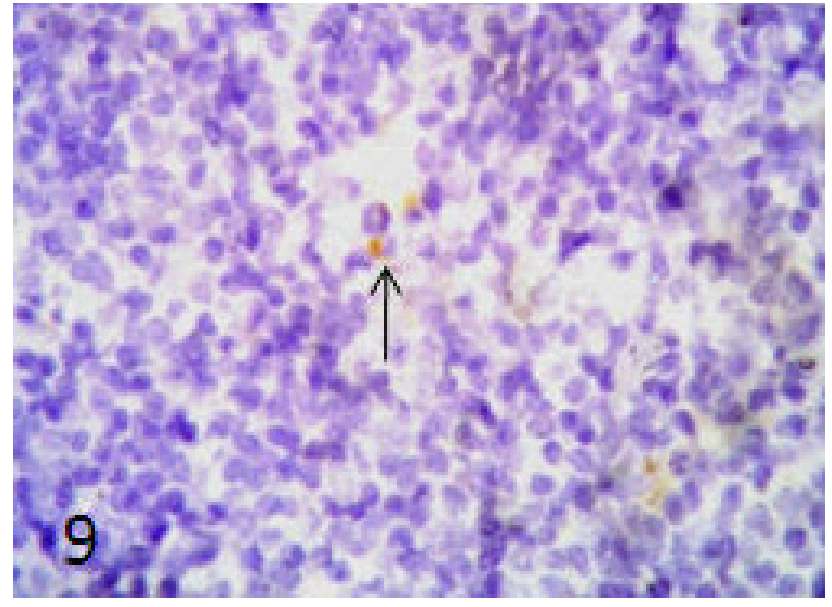

Fig. 9: A photomicrograph of the thymus of group II immunostained for CD8 showing few scattered immunopositive cells at the corticomedullary junction (black arrow).

Immunoperoxidase reaction for CD8X1000

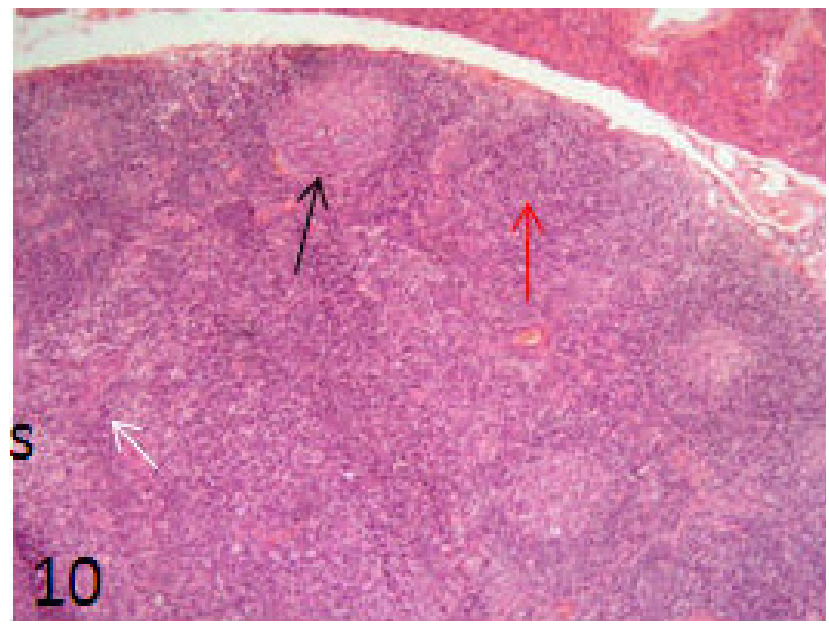

Fig. 10: A photomicrograph of a section in the lymph node from group I showing the cortex with primary lymphatic nodules (red arrow) and secondary lymphatic nodules with dark corona and pale stained germinal centre (black arrow). Medulla with dark stained cords (white arrow) and lightly stained sinuses (S).

$\mathrm{H} \& \mathrm{E} \times 100$

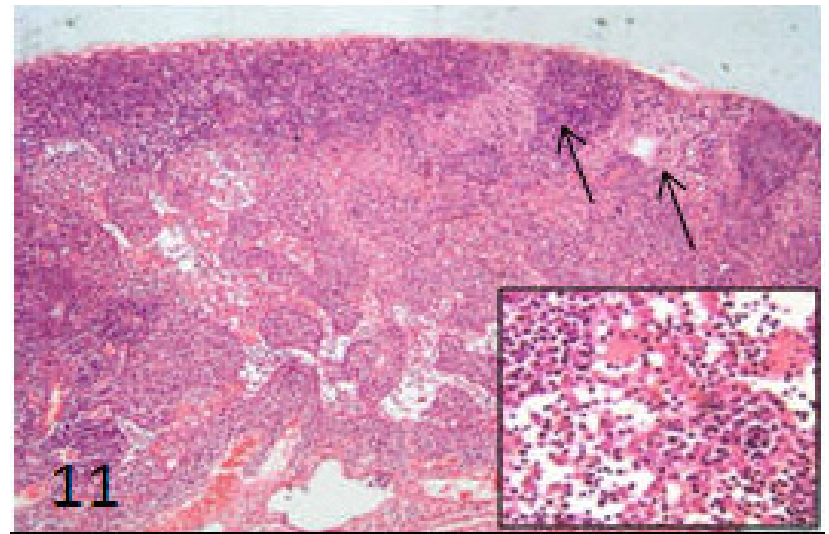

Fig. 11: A photomicrograph of a section in the lymph node from group II showing the cortex with areas of depleted lymphocyte and small disorganized follicles (arrows) . The medullary sinuses are markedly dilated. Inset showed higher magnification of the medullary sinuses.

$\mathrm{H} \& \mathrm{E}, \times 100$ InsetX400
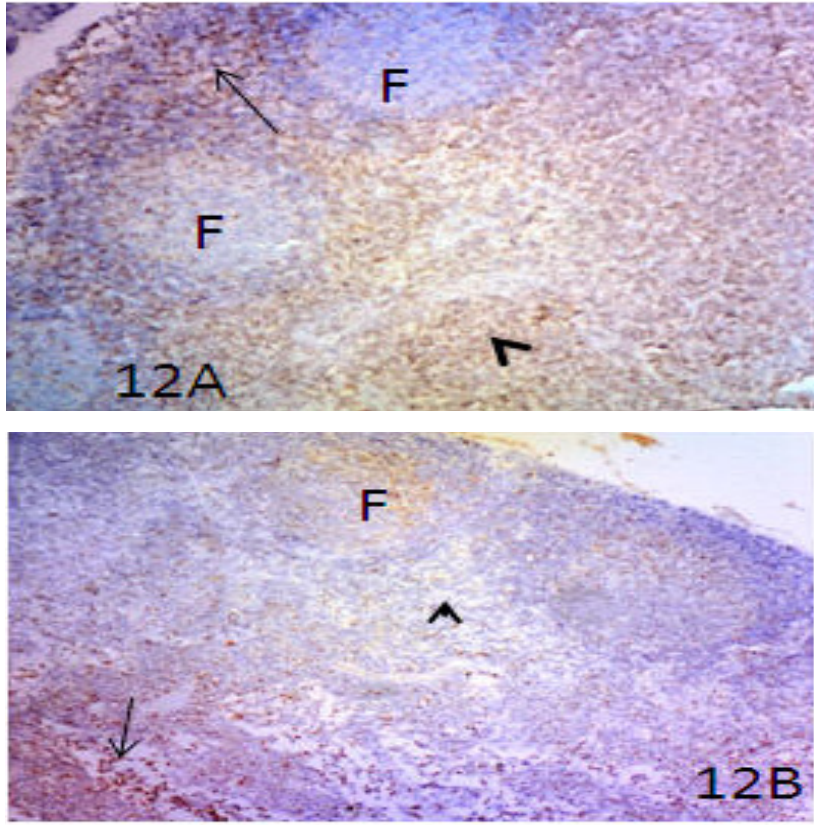

Fig. 12A: A photomicrograph of a section in the lymph node from group I Immunostained for CD3 showing numerous T-cells in the sub capsular (arrow) and paracortical zone (arrowhead) and with minimal expression in the lymphoid follicles $(\mathrm{F})$. B. A photomicrograph of a section in the lymph node from group II Immunostained for CD3 showing lower expression in the paracotex (arrowhead), higher expression within the lymphoid follicles (F). Notice some positive stained T-cells in the medulla (arrow).

Immunoperoxidase reaction for $\mathrm{CD} 3 \mathrm{X} 400$
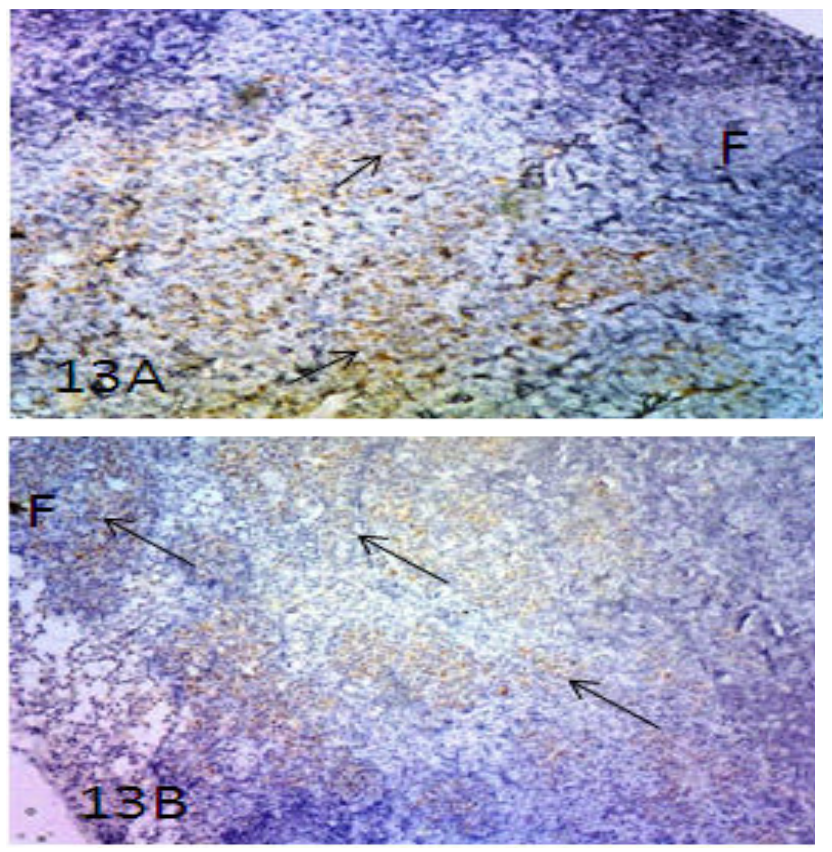

Fig. 13A: A photomicrograph of a section in the lymph node from group I Immunostained for CD4 showing positive immunostained cells in the paracortex and medulla (arrows). B. A photomicrograph of a section in the lymph node from group II Immunostained for CD4 showing high positive expression within the lymphoid follicles (F), in the paracotex and in the medulla (arrows).

Immunoperoxidase reaction for $\mathrm{CD} 4 \mathrm{X} 400$ 

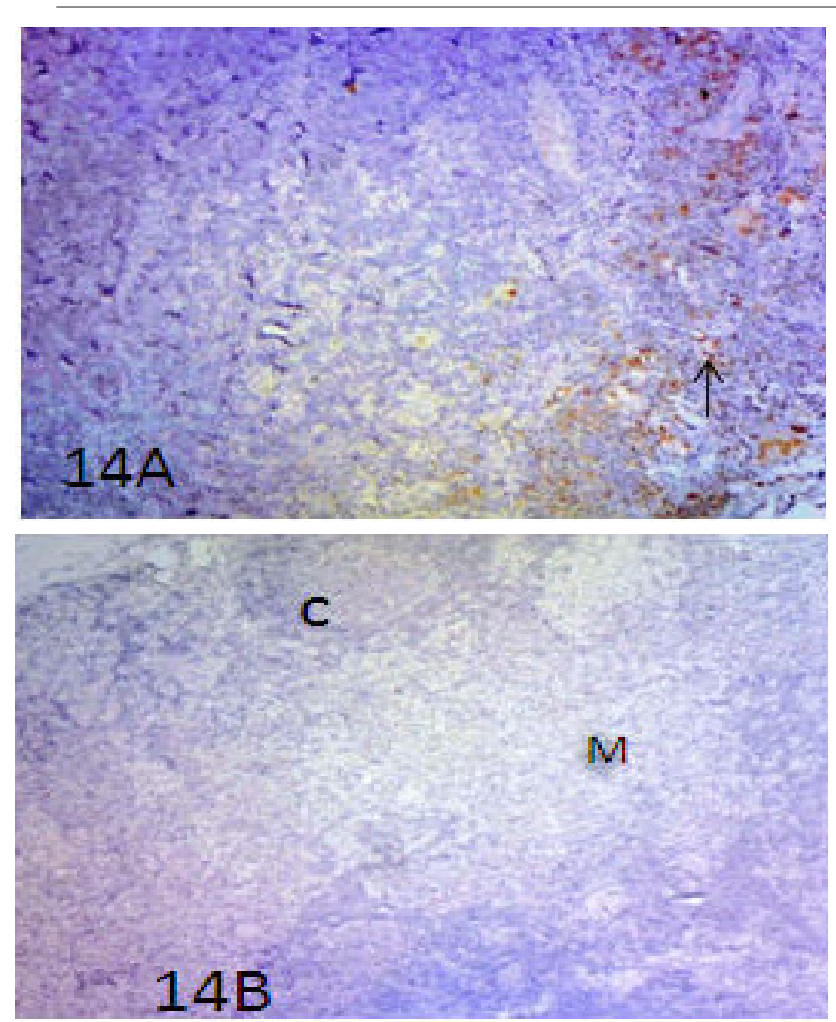

Fig. 14A: A photomicrograph of a section in the lymph node from group I Immunostained for CD8 showing numerous positive immunostained cells in the medulla (arrow). B. A photomicrograph of a section in the lymph node from group II Immunostained for $\mathrm{CD} 8$ showing negative expression in both cortex $(\mathrm{C})$ and medulla $(\mathrm{M})$.

Immunoperoxidase reaction for CD8X400.

\section{DISCUSSION}

Light controls circadian, neuroendocrine and neurobehavior and it has a profound effect on the health of all mammals ${ }^{[30]}$. Disruptive lighting affects many physiological and behavioral functions ${ }^{[8]}$. Chronic exposure of adult female rats to constant light, presumably acts via activating the stress system ${ }^{[31]}$. Nighttime lighting may affect immune function ${ }^{[7]}$. The immune system is compartmentalized and the response to a stressor might be different on each compartment ${ }^{[32]}$. This study investigated the effects of chronic exposure to constant light on the $\mathrm{T}$ lymphocytes populations in the thymus and lymph node.

In the present study, H\&E stained sections, lymphocytic depletion was noticed in the thymic cortex and lymph node sections of the constant light exposure group, many lymphocytes acquired apoptotic morphology with shrunken pyknotic nuclei. In agreement with this study, Mahmoud et al. $1994^{[33]}$, demonstrated that a 1-month period of permanent light causes structural changes in the rat thymus such as reduced cellularity, and increased apoptosis, especially in the cortex. Visible light exposure affects the pituitary and pineal glands and leads to neuroendocrine changes. Melatonin level decreases, while cortisol level increases ${ }^{[34]}$. Continuous light is one of environmental stressor ${ }^{[35]}$. Stress causes marked increase in apoptosis inside the thymus ${ }^{[32]}$. Stress induces activation of the sympathoadrenal medulla and the hypothalamo hypophyseal axis. This stimulates the secretion of catecholamine (noradrenalin and adrenalin) and glucocorticoids. Those are capable of modulating immune cells and further modulating cytokine production ${ }^{[36]}$. High doses of glucocorticoids lead to apoptosis in some cells like thymocytes, T cells, B cells and macrophages, while opposite effect is noticed in neutrophils ${ }^{[37]}$. A critical role for a novel factor, tumor necrosis factor alphainduced protein 8 (TNFAIP8) in glucocorticoidsinduced thymocyte apoptosis was recently identified. TNFAIP8 contains a death effector domain (DED) ${ }^{[38]}$. MicroRNA bioprocessing plays an important role in glucocorticoids -induced apoptosis in lymphocytes ${ }^{[39]}$.

Melatonin is known to be the hormone of darkness and exhibits direct and indirect antioxidant properties ${ }^{[23]}$. Melatonin reduced oxidative stress effects and had anti-apoptotic effects on rat lymphocytes ${ }^{[40]}$. The result of Escribano et al. 2014 ${ }^{[23]}$, showed that permanent light periods led to a significant drop in melatonin level in plasma and pineal gland tissue. They also reported that light increases the lipoperoxide levels and reduce the antioxidative stress biomarkers. Lymphocytic depletion observed in this study also might be due to enhanced apoptosis caused by oxidative stress.

Both glucocorticoids and melatonin affect thymic epithelial reticular cells. Many degenerated thymic epithelial reticular cells were noticed after constant light exposure. This might be due to accelerated thymic epithelial aging caused by glucocorticoids ${ }^{[41]}$. Low level of melatonin affects functions of thymic epithelial cells. Thymic epithelial cells have specific receptors for melatonin on their cell membrane. Thymic epithelial cells synthesize thymulin peptide that is required for T-cell differentiation and maturation within the thymus gland ${ }^{[42]}$.

In this study, the thymus of the control group (I) showed high cortical expression of CD3 with moderate expression in the medulla. In constant light exposed group (II) the expression was reversed. This is in agreement with Aita et al., 2007 ${ }^{[43]}$, who found that in normal thymuses, the cortical lymphocytes showed strong membrane immune staining forming the characteristic ring and the medullary lymphocytes were also positive. The lower expression of CD3 noticed in the cortex of the group II exposed to continuous light might be due to apoptosis affecting immature lymphocytes populating the thymic cortex. Domínguez-Gerpe and Rey-Méndez 2001 ${ }^{[32]}$ found 
that stress caused a marked increase in apoptosis inside the thymus, and a reduction in the total number of thymocytes especially the immature thymocytes. Immature $\mathrm{T}$ cells developing in the thymus are particularly sensitive to stress than the mature one. Stress has a strong impact on thymopoiesis through the alteration of the expression of microRNA involved in apoptosis, tolerance, and proliferation. Many of these MicroRNA exhibited a different responsiveness in immature versus mature thymocyte subsets ${ }^{[44]}$. The moderate CD3 expression appeared in the medulla of group II might be due to their resistance to apoptosis and so escaping the negative selection occurred mostly in the medulla. These cells usually became an autoreactive $\mathrm{T}$ cells $\mathrm{s}^{[45]}$.

In the lymph node of group I, the expression of CD3 was high in the subcapsular area and in the paracortex with minimal expression in the lymphatic follicles while in the continuous light exposed group II the expression was lower than the control group. Some lymphoid follicles showed higher expression, while the paracortex zone showed lower expression. The expression of CD3 in mouse and rat lymph node was usually localized in the paracortex area ${ }^{[46]}$. Liu et al. 2012 $2^{[47]}$, found reduction in CD3 positive $\mathrm{T}$ cells in the mesenteric lymph node in heat stressed rats. Glucocorticoids impair lymphocyte migration to lymph nodes. High level of endogenous cortisol, act via glucocorticoids receptor activation, causes an increase in $\mathrm{C}-\mathrm{X}-\mathrm{C}$ chemokine receptor type 4 (CXCR4) expression and the extravasation of naive $\mathrm{T}$ cells. CXCR4 mediates the homing of $\mathrm{T}$ cells to lymph nodes ${ }^{[48]}$. Glucocorticoids affect $\mathrm{T}$ cells which had lymph node-homing capacity and redirect them from the blood to the bone marrow ${ }^{[49]}$. The appearance of many CD3 positive cells in the lymphoid follicles could be explained by the finding of Hoshi et al., $2002^{[50]}$ who found dividing $\mathrm{T}$ cells engaged in the cell cycle moved towards the germinal center from $\mathrm{T}$ dependant zone. Most of those cells were CD4 and CD8 positive cells.

Morphometric analysis showed that the number of CD4 and CD8 positive cells was decreased in the continuous exposed light group II in comparison to the control group I. The decrease in the number of CD4 and CD8 positive cells might be as a result of failure of T-cell differentiation and maturation ${ }^{[42]}$. Large stress period causes large thymic involution with decrease in $\mathrm{CD} 4+$ and $\mathrm{CD} 8+$ populations on the thymus. This happens to counteract the effect of the increased peripheral demand of $\mathrm{T}$ cells from thymus ${ }^{[32]}$.

In the lymph node the CD4 positive cells appeared in the paracortex and medulla, while in continuous light exposed group II the CD4 positive cells were noticed in the lymphoid follicles, paracortex and medulla.
CD4 positive cells appeared in the follicle might be the CD4 positive follicular T helper cells (TFH) that compose a heterogeneous subset of CD4+ $\mathrm{T}$ cells that induce the differentiation of $\mathrm{B}$ cells into plasma cells and memory cells. They are found within and in proximity to germinal centers in secondary lymphoid $\operatorname{organs}^{[51]}$. T follicular helper cells are a major class of Interleukin-4 producing T cells, required for regulation of type 2 humoral immunity. Interleukin-4 (IL-4) was identified as a B cell-stimulating factor critical for class-switch ${ }^{[52]}$. Circadian disruption also would result in aberrant changes to miRNAs ${ }^{[53]}$. Micro RNA (miRNA) was found to be involved in the regulation of TFH cells. Abnormal control TFH could induce autoimmune disease ${ }^{[53]}$.

Negative staining for CD8 was noticed in the lymph node of group II in comparison to group I. This might be due to stress induced glucocorticoids production. Nair et al., 2007(55) found that the number of CD8 (+) $\mathrm{T}$ cells in the superficial cervical lymph nodes was decreased in stressed mice via glucocorticoid receptormediated mechanisms. Suppression of CD8+ T cell immune response is resulting in diminished antiviral immunity ${ }^{[56]}$.

\section{CONCLUSION}

It can be concluded that, constant light exposure has significant consequences on the immune system. Constant light stress causes lymphocytic depletion and alters lymphoid cell subsets distribution both in the thymus and lymph node. This alteration might cause abnormal immune response including autoimmune response.

\section{CONFLICT OF INTEREST}

There are no conflicts of interest.

\section{REFERENCES}

1. Hardeland R. (2012): Melatonin in aging and disease -multiple consequences of reduced secretion, options and limits of treatment. Aging Dis; 3(2): 194 -225.

2. Tolson K.P., and Chappell P.E. (2012): The Changes They are A-Timed: Metabolism, Endogenous Clocks, and the Timing of Puberty. Front Endocrinol (Lausanne); 3: 45.

3. Reiter R.J. (1991): Pineal gland interface between the photoperiodic environment and the endocrine system. Trends in Endocrinology and Metabolism; 2: 13- 19.

4. Pandi-Perumal S.R., Srinivasan V., Maestroni G.J., Cardinali D.P., Poeggeler B., and Hardland R. (2006): Melatonin: Nature's most versatile biological signal?. FEBS J; 273: 2813-2838. 
5. Gu"ndu"z B. (2002): Daily rhythm in serum melatonin and leptin levels in the Syrian hamster (Mesocricetus auratus). Comp Biochem Physiol A Mol Integr Physiol; 132(2):393 -401.

6. Içten N., Karagöz F., and Güneç K. A. (1998): The Effects of Constant Darkness and Constant Light on the Pineal Gland and Thymus Morphology in the Rats. Tr. J. of Medical Sciences; 28: 7- 12.

7. Fonken L.K., Haim A. and Nelson R.J. (2012): Dim Light at Night Increases Immune Function in Nile Grass Rats, a Diurnal Rodent. Chronobiology International; 29(1): 26-34.

8. Fonken L.K., and Nelson R.J. (2011): Illuminating the deleterious effects of light at night. F1000 Med. Rep.; 3:18.

9. Ha M, and Park J. (2005): Shiftwork and metabolic risk factors of cardiovascular disease. J. Occup. Health; 47:89-95.

10. Kloog I., Portnov B.A., Rennert H.S., and Haim A. (2011): Does the modern urbanized sleeping habitat pose a breast cancer risk?. Chronobiol. Int.; 28:76-80.

11. Fonken L.K., Finy M.S., Walton J.C., Weil Z.M., Workman J.L., Ross J., and Nelson R.J. (2009): Influence of light at night on murine anxiety- and depressive-like responses. Behav. Brain Res.; 205:349-354.

12. Dauchy R.T., Dauchy E.M., Tirrell R.P., Hill C.R., Davidson L.K., GreeneM.W., Tirrell P.C., Wu J., Sauer L.A., and Blask D.E. (2010): Dark-phase light contamination disrupts circadian rhythms in plasma measures of endocrine physiology and metabolism in rats. Comp. Med.; 60:348-356.

13. Carrillo-Vico A., Guerrero J.M., Lardone P.J., and Reiter R.J., (2005): A review of the multiple actions of melatonin on the immune system. Endocrine.; 27:189-200.

14. McEwen B.S. (2000): The neurobiology of stress: from serendipity to clinical relevance (1). Brain Res.; 886:172- 189 .

15. Welberg L., Thrivikraman K.V., and Plotsky P.M. (2006): Combined pre- and postnatal environmental enrichment programs the HPA axis differentially in male and female rats. sychoneuroendocrinology; 31:553-64.

16. Padgett D.A., and Glaser R. (2003): How stress influences the immune response. Trends Immunol.; 24:444-8. Padgett D.A., and Glaser R. (2003):
How stress influences the immune response. Trends Immunol.; 24:444-8.

17. Mastorakos G., and Ilias I. (2000): Maternal hypothalamic-pituitary-adrenal axis in pregnancy and the postpartum period. Post partum related disorders. Ann N Y Acad Sci.; 900:95- 106.

18. Lissoni P., Barni S., Tancini G., and Rovelli F. (1993): A stud Bancroft J.D., and Stevens A. (1996): Theory and practice of histological techniques, 4th ed. Edinburgh: Churchill Livingstone. $y$ of the mechanism involved in the immunostimulatory action of the pineal hormone in cancer patients. Oncology; 50:399-402.

19. Goldrath A. W., and Bevan M.J. (1999): Selecting and maintaining a diverse T-cell repertoire. Nature; 402: 255-262.

20. Abbas A.K., Kumar V., Fausto N., Robbins S.L., and Cotran R.S. (2004): Diseases of immunity. In: Robbins and Cotran, Pathologic Basis of Diseases $7^{\text {th }} \mathrm{ed}$, 193 -267.pp. 193-267.

21. Korn T., Bettelli E., Oukka M. and Kuchroo V.K. (2009): IL-17 and Th17 Cells. Annual Reviews of Immunology; 27: 485- 517.

22. Smith-Garvin J. E., Koretzky G.A., and Jordan M.S. (2009): T cell activation. Annu. Rev. Immunol.; 27: 591-619.

23. Escribano B.M., Díaz-Moreno A., Tasset I., and Tu' nez I. (2014): Impact of Light/Dark Cycle Patterns on Oxidative Stress in an Adriamycin-Induced Nephropathy Model in Rats. 9(5).

24. Bancroft J.D., and Stevens A. (1996): Theory and practice of histological techniques, $4^{\text {th }}$ ed. Edinburgh: Churchill Livingstone.

25. Mason D.Y., Cordell J., Brown M., Pallesen G., Ralfkiaer E., Rothbard J., Crumpton M., and Gatter K.C. (1989): Detection of cells in paraffin wax embedded tissue using antibodies against a peptide sequence from the CD3 antigen. J Clin Pathol 42:1194- 1200 .

26. Leong A. S-Y, Cooper K., and Leong F. J. (2003): Manual of diagnostic antibodies for immunohistology, second ed. Greenwich Medical Media Ltd: p. 65- 6.

27. Mason D.Y., Cordell J.L., Gaulard P., Tse A.G.D., and Brown M.H. (1992): Immunohistological detection of human cytotoxic/suppressor $\mathrm{T}$ cells using antibodies to a CD8 peptide sequence. J Clin Pathol; 45:1084- 8. 
28. Côté A., Da Silva R., and Cuello A.C. (1993): Current protocols for light microscopy. immunocytochemistry. In: Cuello AC, editor. Immunohistochemistry II: John Wiley \& Sons, Chichester 147- 168.

29. Tulic M.K., Sly P. D., Andrews D., Crook M., Davoine F., Odemuyiwa S.O., Charles A., Hodder M.L., Prescott S. L., Holt P. G., and Moqbel R. (2009): Thymic Indoleamine 2,3-DioxygenasePositive Eosinophils in Young Children Potential Role In Maturation of the Naive Immune System. Am J Pathol.; 175(5): 2043-2052.

30. Dauchy R.T., Dauchy E.M., Hanifin J.P., Gauthreaux S.L., Mao L., Belancio V.p., Ooms T.g., M., Jablonski M.R., Warfield B., Wren M.A., Brainard G.C., Hill S.S., and Blask D.E. (2013): Effects of spectral transmittance through standard laboratory cages on circadian metabolism and physiology in nude rats. $\mathrm{J}$ Am Assoc Lab Anim Sci.; 52: 146-156.

31. Miloševi' V., Trifunovi' S., Sekuli' M., Šoši'c-Jurjevi' B., Filipovi' B. Negi' N., Nestorovi' N., Stojanoski M., and Starčevi' V. (2005): Chronic Exposure to Constant Light Affects Morphology and Secretion of Adrenal Zona Fasciculata Cells in Female Rats. Gen. Physiol. Biophys., 24, 299-309.

32. Domínguez-Gerpe L, and Rey-Méndez M., (2001): Alterations induced by chronic stress in lymphocyte subsets of blood and primary and secondary immune organs of mice. BMC Immunology; 2:7.

33. Mahmoud I., Salman S.S., and Al-Khateeb A. (1994): Continuous darkness and continuous light induce structural changes in the rat thymus. J. Anat.; 185, 143-149.

34. Brainard G. J., French P., Hannon M., Rollag J., Hanifin W., and Storm L. (1991): Effects of bright illumination on melatonin, prolactin and cortisol rhythms in subjects during sustained wakefulness. Soc. Light Treatment Bio. Rhythms Abstr.; 3: 16.

35. Harkin A., Connor T.J., O'Donnell J.M., and Kelly J.P. (2002). Physiological and behavioral responses to stress: what dose a rat find stress ful. Lab Animal; 31(4): $42-50$.

36. Liu Y-L., Hui B., Chi S-M., Fan R., Wang Y-M., Ma X-L., Chen Y-M, Luo W-J, Pei J-M, and Chen J-Y. (2007): The effect of compound nutrients on stressinduced changes in serum IL-2, IL- 6 and TNF- $\alpha$ levels in rats. Cytokine.; 37:14-21

37. Amanda L., Yates G., and Cidlowski J. A. (2013): Tissue-Specific Actions of Glucocorticoids on
Apoptosis: A Double-Edged Sword Cells. Jun; 2(2): 202-223.

38. Woodward M.J., De Boer J., Heidorn S., Hubank M., Kioussis D., Williams O., and Brady H.J. (2010):Tnfaip8 is an essential gene for the regulation of glucocorticoid-mediated apoptosis of thymocytes. Cell Death Differ.; 17:316-323.

39. Smith L.K., Shah R.R., and Cidlowski J.A. (2010): Glucocorticoids modulate microRNA expression and processing during lymphocyte apoptosis. J. Biol. Chem.; 285:36698-36708.

40. Tu'nez I., and Montilla P. (2007): Neuroprotective role of melatonin against Alzheimer's disease, Huntington's disease and other cerebral disorders. In: Tu'nez I; Montilla P, editors. Melatonin present and future. New York: Nova Science Publishers, Inc. pp. 315-347.

41. Talaber G., Kvell K., Varecza Z., Boldizsar F., Parnell S. M., Jenkinson E. J., Anderson G., Berki T., Judit E., and Pongracz J. E.( 2011):Thymic Epithelial Cells Against Dexamethasone-Induced Senescence. Rejuvenation Res.; 14 (3): 241-248.

42. Mocchegiani E., Malavolta M., Costarelli L., Giacconi R., Piacenza F., Lattanzio F., and Basso A. (2013): there a possible single mediator in modulating neuroendocrine-thymus interaction in ageing? Curr Aging Sci.; 6(1):99 -107.

43. Aita M., Carafelli E., Alfei L., and Caronti B., (2007):Thymic development in surgically bursectomized embryonic chicken: expression of PCNA, CD3, CD4 and CD8 markers. European Journal of Histochemistry; 51(4):241- 250.

44. Belkaya S., Silge R. L., Hoover A. R., Medeiros J. J., Eitson J. L., Becker A. M., Morena M. T., BasselDuby R. S., and Van Oers N.S.C. (2011): Dynamic Modulation of Thymic MicroRNAs in Response to Stress. PLoS ONE 6(11): e27580.

45. Palmer E.D.(2003): Negative selection - clearing out the bad apples from the T-cell repertoire. Nature Reviews Immunology 3, 383- 391.

46. Ward J. M., Erexson C. R., Faucette L. J., Foley J. F., Dijkstra C., and Cattoretti G. (2006): Immunohistochemical Markers for the Rodent Immune System. Toxicologic Pathology, 34:616-630.

47. Liu X., Li H., Lu A., Zhong Y., Hou X., Wang N., Jia D., Zan J., Zhao H., Xu J., and Liu F. (2012): Reduction of intestinal mucosal immune function in heat-stressed 
rats and bacterial translocation. Int $\mathrm{J}$ Hyperthermia.; 28(8):756- 65

48. Besedovsky L., Born J., and Lange T.(2014): Endogenous glucocorticoid receptor signaling drives rhythmic changes in human T-cell subset numbers and the expression of the chemokine receptor CXCR4 . The FASEB Journal ; 2 ( 1): 67- 75.

49. Okutsu M., Ishii K., Niu K. J., and Nagatomi R. (2005): Cortisol-induced CXCR4 augmentation mobilizes $\mathrm{T}$ lymphocytes after acute physical stress. Am. J. Physiol.; 288:591-599

50. Hoshi S., Bouzahzah F., Mancini I., and Antoine N.(2002):Location and Phenotype of Proliferating $\mathrm{T}$ cells in secondary lymph follicle. J. Clin. Exp. Hematopathol.; 42, No.1.

51. Ueno H., Banchereau J., and Carola G. (2015):Pathophysiology of T follicular helper cells in humans and mice. Nature Immunology 16: 142-152.

52. Sahoo A., Alekseev A., Tanaka K., Obertas L., Lerman B., Haymaker C., Clise-Dwyer K., McMurray J.S.. and Nurieva R (2015): Batf is important for IL-4 expression in $\mathrm{T}$ follicular helper cells. Cytokine; 76 (1): 104

53. Kochan D. Z., Ilnytskyy Y., Golubov A., Deibel S.H., McDonald R.J., and Kovalchuk O. ( 2015): Circadian disruption-induced microRNAome deregulation in rat mammary gland tissues. Oncoscience.; 2(4): 428-442.

54. Park H.J., Kim D..H, Lim S..H, Kim W.J., Youn J., Choi Y.S., and Choi J.M. (2014): Insights into the role of follicular helper $\mathrm{T}$ cells in autoimmunity. Immune Netw.; 14(1):21- 9 .

55. Nair A., Hunzeker J., and Bonneau R.H. (2007) Modulation of microglia and CD8(+) T cell activation during the development of stress-induced herpes simplex virus type-1 encephalitis. Brain Behav Immun.; 21(6):791- 806.

56. Elftman M.D., Hunzeker J. T., Mellinger J. C., Bonneau R. H., Norbury C.C., and Truckenmiller M.E.(2010): Stress-Induced Glucocorticoids at the Earliest Stages of Herpes Simplex Virus-1 Infection Suppress Subsequent Antiviral Immunity, Implicating Impaired Dendritic Cell Function. J Immunol.; 184(4):1867 -75 
الملخص العربى

دراسة هستولوجية و هستوكيميائية مناعية لتأثير التعرض المستمر للضوع على انواع الخلايا

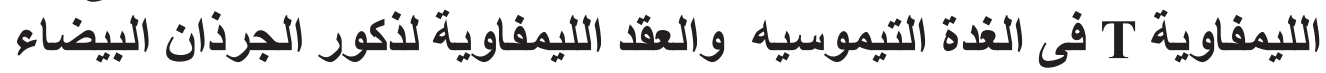

رحاب أحمد رفاعى 1 و فاطمة فؤاد عبدالباقى 2

$$
\text { اقسم الهستولوجيا ـ كلية الطب ـ جامعة المنيا ـ المنيا ـ مصر }
$$

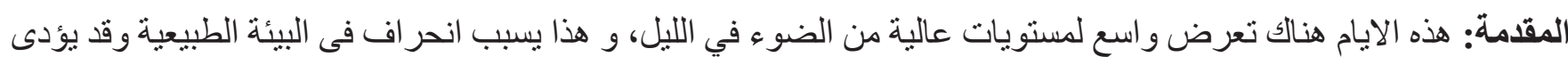

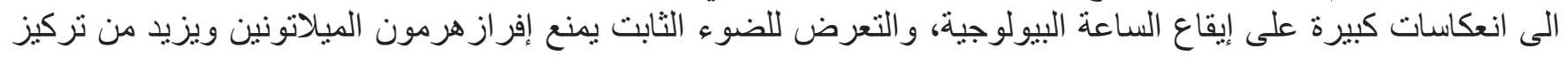

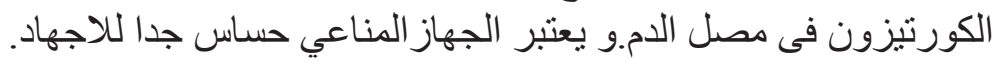

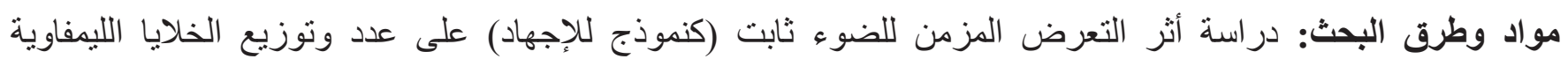

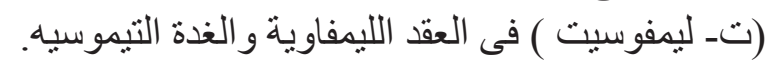

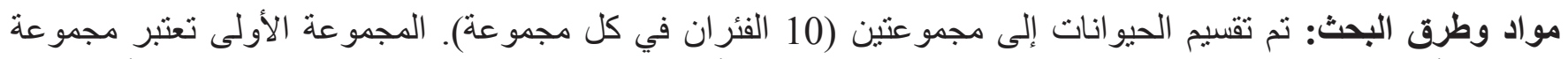

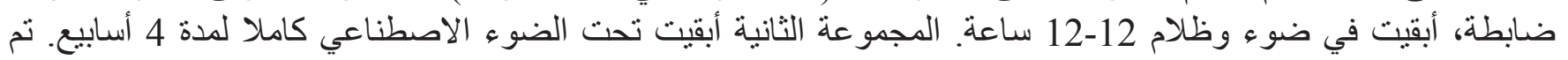

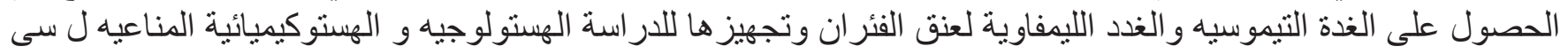

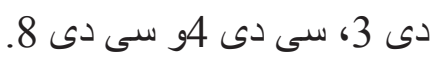

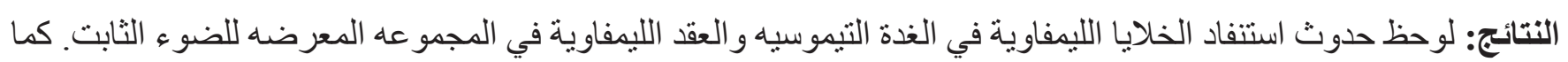

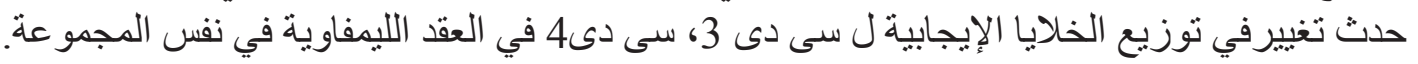

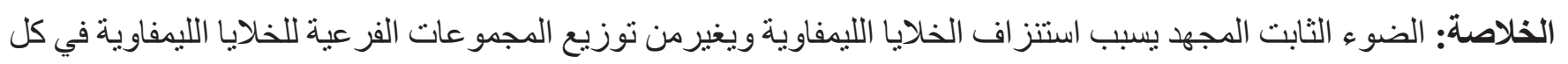
من العقد الليمفاوية والغدة التيموسيه. 